\title{
Cancer risk in 680000 people exposed to computed tomography scans in childhood or adolescence: data linkage study of 11 million Australians
}

\author{
(a) (1) $\Theta$ OPEN ACCESS
}

\begin{abstract}
John D Mathews epidemiologist ${ }^{1}$, Anna V Forsythe research officer ${ }^{1}$, Zoe Brady medical physicist ${ }^{12}$, Martin W Butler data analyst ${ }^{3}$, Stacy K Goergen radiologist ${ }^{4}$, Graham B Byrnes statistician ${ }^{5}$, Graham G Giles epidemiologist ${ }^{6}$, Anthony B Wallace medical physicist ${ }^{7}$, Philip R Anderson epidemiologist ${ }^{89}$, Tenniel A Guiver data analyst ${ }^{8}$, Paul McGale statistician ${ }^{10}$, Timothy M Cain radiologist $^{11}$, James $G$ Dowty research fellow ${ }^{1}$, Adrian C Bickerstaffe computer scientist ${ }^{1}$, Sarah C Darby statistician ${ }^{10}$
\end{abstract}

${ }^{1}$ School of Population and Global Health, University of Melbourne, Carlton, Vic 3053, Australia; ${ }^{2}$ Department of Radiology, Alfred Health, Prahran, Vic, Australia; ${ }^{3}$ Medical Benefits Scheme Analytics Section, Department of Health and Ageing, Canberra, ACT, Australia; ${ }^{4}$ Department of Diagnostic Imaging, Southern Health, and Monash University Southern Clinical School, Clayton, Vic, Australia; ${ }^{5}$ Biostatistics Group, International Agency for Research on Cancer, Lyon, France; ${ }^{6}$ Cancer Epidemiology Centre, Cancer Council Victoria, Carlton, Vic, Australia; ${ }^{7}$ Diagnostic Imaging and Nuclear Medicine Section, Australian Radiation Protection and Nuclear Safety Agency, Yallambie, Vic, Australia; ${ }^{8}$ Data Linkage Unit, Australian Institute of Health and Welfare, Canberra, Australia; ${ }^{9}$ Faculty of Health, University of Canberra, Canberra, Australia; ${ }^{10} \mathrm{Clinical}$ Trial Service Unit and Epidemiological Studies Unit, University of Oxford, Oxford, UK; ${ }^{11}$ Medical Imaging, Royal Children's Hospital Melbourne, Parkville, Vic, Australia

\begin{abstract}
Objective To assess the cancer risk in children and adolescents following exposure to low dose ionising radiation from diagnostic computed tomography (CT) scans.

Design Population based, cohort, data linkage study in Australia.

Cohort members 10.9 million people identified from Australian Medicare records, aged 0-19 years on 1 January 1985 or born between 1 January 1985 and 31 December 2005; all exposures to CT scans funded by Medicare during 1985-2005 were identified for this cohort. Cancers diagnosed in cohort members up to 31 December 2007 were obtained through linkage to national cancer records.

Main outcome Cancer incidence rates in individuals exposed to a CT scan more than one year before any cancer diagnosis, compared with cancer incidence rates in unexposed individuals.

Results 60674 cancers were recorded, including 3150 in 680211 people exposed to a CT scan at least one year before any cancer diagnosis. The mean duration of follow-up after exposure was 9.5 years. Overall cancer incidence was $24 \%$ greater for exposed than for unexposed people, after accounting for age, sex, and year of birth (incidence rate ratio (IRR) 1.24 (95\% confidence interval 1.20 to 1.29 ); $\mathrm{P}<0.001)$. We saw a dose-response relation, and the IRR increased by 0.16 ( 0.13 to $0.19)$ for each additional CT scan. The IRR was greater after exposure
\end{abstract}

at younger ages $(P<0.001$ for trend). At $1-4,5-9,10-14$, and 15 or more years since first exposure, IRRs were 1.35 (1.25 to 1.45), 1.25 (1.17 to 1.34), 1.14 (1.06 to 1.22 ), and 1.24 (1.14 to 1.34 ), respectively. The IRR increased significantly for many types of solid cancer (digestive organs, melanoma, soft tissue, female genital, urinary tract, brain, and thyroid); leukaemia, myelodysplasia, and some other lymphoid cancers. There was an excess of 608 cancers in people exposed to CT scans (147 brain, 356 other solid, 48 leukaemia or myelodysplasia, and 57 other lymphoid). The absolute excess incidence rate for all cancers combined was 9.38 per 100000 person years at risk, as of 31 December 2007. The average effective radiation dose per scan was estimated as 4.5 mSv.

Conclusions The increased incidence of cancer after CT scan exposure in this cohort was mostly due to irradiation. Because the cancer excess was still continuing at the end of follow-up, the eventual lifetime risk from CT scans cannot yet be determined. Radiation doses from contemporary CT scans are likely to be lower than those in 1985-2005, but some increase in cancer risk is still likely from current scans. Future CT scans should be limited to situations where there is a definite clinical indication, with every scan optimised to provide a diagnostic CT image at the lowest possible radiation dose. 


\section{Introduction}

Although computed tomography (CT) scans have great medical benefits, their increasing use since the 1980s has raised concerns about possible cancer risks, particularly after exposures in childhood. ${ }^{1-12}$ Doses of ionising radiation from CT scans are typically in the range of 5-50 mGy to each organ imaged, ${ }^{1891314}$ and until recently, it was thought impractical to estimate directly the risk of cancer after such low doses, because of the large number of exposures and outcomes needed in cohort studies, and the potential for bias in some case-control designs. ${ }^{15} 16$ Accordingly, risks have usually been estimated indirectly, by projecting the risks seen after exposures at higher doses, such as in the Life Span Study of survivors of the Japanese atomic bombings. ${ }^{17-20}$

Studies of occupational exposure to radiation have provided some direct estimates of the risk at lower doses for adults. ${ }^{21} \mathrm{~A}$ recent follow-up study of 180000 young people who had CT scans in the United Kingdom during 1985-2002 reported increasing risks of leukaemia and brain cancer with increasing doses of radiation from a previous CT scan, and gave provisional risk estimates for these two cancers. ${ }^{12}$ Some radiation experts have, however, questioned the validity of these estimates, ${ }^{22}$

while others have questioned the validity of the earlier indirect estimates based on the projected risks. ${ }^{23}$ Thus, there is currently much uncertainty as to whether any material cancer risk exists from CT scan exposures.

Australia has a large number of CT scanners per capita, ${ }^{89}$ and public funding of CT services under the comprehensive

Medicare scheme has allowed us to study a CT exposed cohort drawn from the general population. ${ }^{9}$ In this paper, we derived direct estimates of the increased cancer risk in the first decade or so after CT scan exposure by comparing cancer incidence in over 680000 people exposed to CT scans at ages 0-19 years with cancer incidence in a comparison cohort of over 10 million unexposed persons of similar age.

\section{Methods}

The Australian Medicare system has records of health services for all Australians, which are federally funded on a fee-for-service basis. Electronic Medicare records were accessed to identify all Australians aged 0-19 years on 1 January 1985 , or born during the period 1 January 1985 to 31 December 2005. The cohort was followed to 31 December 2007 by electronic linkage to the Australian Cancer Database and the National Death Index maintained by the Australian Institute of Health and Welfare. Cancer diagnoses were based on ICD-10 (international classification of diseases, 10th revision) codes C00-C96, plus D45, 46, 47.1, and 47.3 for myelodysplasia and related bone marrow disorders. Socioeconomic status was derived from the SEIFA (socioeconomic indexes for areas) index based on residential post codes and validated by the Australian government. ${ }^{24}$ The SEIFA index was used to categorise each person into one of seven approximately equal sized groups, numbered by increasing socioeconomic index. If the index for an individual changed over time, we used the mean value.

We used records of all CT scan exposures in the Medicare database for people aged 0-19 years during the period 1 January 1985 to 31 December 2005. CT scans in state based tertiary hospitals were usually missed, because most of such services are not funded on a fee-for-service basis, and are thus absent from Medicare records. Our study would also have missed CT exposures of cohort members that took place outside Australia, exposures before 1 January 1985 or after 31 December 2005, and exposures in the cohort after the age of 19 years. Records were de-identified before being made available for epidemiological analysis.

Each individual was entered into the study on the latest of the following dates: 1 January 1985, date of birth, or date first known to Medicare. Cohort members remained in the study until their exit date, which was the earliest of the following dates: 31 December 2007, date of death, or date of first cancer diagnosis. A CT scan was defined as an exposure if it occurred on or after the person's entry date, on or before 31 December 2005, when the person was aged 0-19 years, on or before the person's exit date, and at least one year before any diagnosis of cancer.

The exclusion period before a cancer diagnosis, referred to as the lag period, was introduced because of the possibility that the scan was part of the cancer diagnostic procedure. Most analyses were based on lag periods of one year, but we repeated the main analyses with lag periods of five and 10 years to explore the possibility of reverse causation. To calculate person years at risk, we assigned each person to the unexposed group from the date of entry until the transfer date (date of the first CT scan plus any lag period), and to the exposed group from the transfer date until the exit date (fig $1 \Downarrow$ ).

The primary analysis was of incidence rate ratios (IRRs) for exposed versus unexposed individuals by Poisson regression, using the number of person years as an offset, and with stratification by age (single years), sex, and year of birth (two year bands). We used likelihood ratio tests to assess the significance of departures of the IRR from unity. Tests for trend compared Poisson regression models with and without the covariate of interest (for example, the number of scans or the age at first exposure). Floating 95\% confidence intervals for the IRR categorised according to the number of CT scans were calculated using the amount of information in each category. ${ }^{25}$ We estimated the excess number of cancers among the exposed cohort as $(1-(1 \div$ IRR $))$ multiplied by the observed number of cancers in exposed individuals, and we divided this quantity by the total number of person years among exposed individuals to estimate the absolute excess incidence rate (EIR) among the exposed group compared with the unexposed group. Trends in the EIR were tested by least squares regression with inverse variance weighting. Significance tests were two tailed. Procedures were programmed in Stata statistical software, release 12 (StataCorp).

The number of CT scans provided the simplest measure of a person's radiation exposure. Because it was impossible to obtain individual machine parameters for all CT procedures, we estimated average effective doses ${ }^{26}$ per scan (in $\mathrm{mSv}$ ) by site and year of scan, and by age. Effective doses were obtained from the published literature ${ }^{27-33}$ for specific ages (newborn; 1 , $5,10,15$ years; adult) and then mapped to the corresponding age band in the Medicare dataset. In Australian radiological practice, as in the $\mathrm{UK},{ }^{12}$ it was common to adjust machine parameters for the size or age (or both) of the patient to reduce the radiation dose, from 2001 onwards. We derived average effective doses in each age band for each CT category for the periods 1985-2000 and 2001-05. Owing to the lack of data available for paediatric effective doses for the earlier time period, we applied a scaling factor to adult effective doses to infer paediatric effective dose ${ }^{34}$ before 2001 , taking into account the differences in scan length ${ }^{31}$ between adults and children and the variation in $\mathrm{x}$ ray absorption with different body sizes. ${ }^{30}$ Collective effective doses were estimated for the exposed population by cumulating the average doses by type of CT scan, 
year of scan, and age of the individual across all scans, after excluding those exposures that fell within the relevant lag period (one, five, or 10 years). We derived average organ doses for brain and red bone marrow ( $\mathrm{mGy}$ ) from $\mathrm{local}^{33}$ and international sources. $^{13}$

\section{Results \\ Study population and overall risks}

The cohort included 10939680 people. Based on a one year lag period, $680211(6.2 \%)$ were transferred into the CT exposed group before their exit from the study (table $1 \Downarrow$ ), and $18 \%$ of the exposed group had more than one scan (table $2 \Downarrow$ ). Mean length of follow-up was 9.5 years for the exposed group and 17.3 years for the unexposed group. By 31 December 2007, 3150 individuals in the exposed group and 57524 individuals in the unexposed group had been diagnosed with a cancer, giving a total of 60674 people with a cancer. For all types of cancer combined, incidence was $24 \%$ greater in the exposed group than in the unexposed group (IRR 1.24 (95\% confidence interval 1.20 to 1.29) after stratification for age, sex, and year of birth, $\mathrm{P}<0.001)$, and the IRR increased by 0.16 ( 0.13 to 0.19$)$ with each additional CT scan $(\mathrm{P}<0.001$ for trend; fig $2 \Downarrow)$. When the calculations were repeated based on lag periods of five and 10 years, cancer incidence remained higher in the exposed group than in the unexposed group, although the proportional increases were smaller compared with those based on the one year lag period (five year lag period: IRR 1.21 (1.16 to 1.26 ), $\mathrm{P}<0.001$; 10 year lag period: 1.18 (1.11 to 1.24 ), $\mathrm{P}<0.001$; table $3 \Downarrow)$. For lag periods of five and 10 years, the IRR increased by $0.13(0.10$ to 0.16 ) and 0.10 (0.06 to 0.15$)$, respectively, for each additional scan (web fig A).

\section{Risks for specific cancers}

The IRR for the exposed group versus the unexposed group was increased not only for all cancers combined but also for all solid cancers and for all lymphoid and haematopoietic cancers when these were considered separately (table $4 \Downarrow$ ). Among specific malignancies, brain cancer had the largest IRR, although incidence was also increased significantly for cancers of the digestive organs, melanoma, soft tissue, female genital organs, urinary tract, thyroid, ill defined and unspecified sites,

Hodgkin's lymphoma, other lymphoid cancers, leukaemias and myelodysplasias, all leukaemias, myeloid and other leukaemias, and myelodysplasias (table 4). We saw no separate increase in IRR for breast cancer or lymphoid leukaemia. The estimated total number of excess cancers for the exposed group was 608, with melanoma, soft tissue cancers, brain cancer, thyroid cancer, and all lymphoid and haematopoietic cancer each contributing more than 50 cases (table 4). EIRs were 9.38 per 100000 person years for all cancers combined, and more than 1 per 100000 person years each for melanoma, brain cancer, thyroid cancer, and all lymphoid and haematopoietic cancers. Results by cancer type were consistent when we repeated the analysis using lag periods of five and 10 years (web tables A and B, respectively).

\section{Effects of time since exposure, year of exposure, age at exposure, sex, socioeconomic status, and other potential confounding factors}

For brain cancer, both the proportional increase in the incidence rate and the absolute excess incidence rate in the exposed group were greatest 1-4 years after first CT exposure, after which they declined ( $\mathrm{P}<0.001$ for IRR trend, $\mathrm{P}=0.03$ for EIR trend). Nevertheless, brain cancer incidence was still increased significantly at 15 or more years following first exposure (table $5 \Downarrow)$. For other solid cancers, there was no significant trend in the proportional increase in incidence rate with time since first exposure ( $\mathrm{P}=0.88$ for IRR trend), although the absolute excess incidence rate increased with time since first exposure $(\mathrm{P}=0.01$ for EIR trend). For leukaemias and myelodysplasias and for other lymphoid and haematopoietic cancers, there were no significant trends with time since first exposure in either the proportional increase (IRR) or the absolute increase (EIR) in incidence rate. For all cancers combined, the proportional increase in the incidence rate declined with years since the first $\mathrm{CT}$ scan $(\mathrm{P}=0.009$ for IRR trend), but the incidence rate for all cancers combined in the exposed group was still increased at 15 or more years after first exposure (IRR 1.24, 95\% confidence interval 1.14 to 1.34). We saw no significant trend in EIR for all cancers combined $(\mathrm{P}=0.43$ for trend).

For brain cancer, the IRR for a given time since first exposure was less if the exposure happened in a later calendar period $(\mathrm{P}<0.001$ for trend), but for all solid cancers other than brain cancer and for all cancers combined, the trends in IRR with calendar period of first exposure were not significant $(\mathrm{P}=0.68$ and $\mathrm{P}=0.18$, respectively; table $6 \Downarrow$, web table $\mathrm{C}$, web figs $\mathrm{B}$ and C).

For brain cancer and for all cancers combined, IRRs were highest for CT exposures in children younger than 5 years, and decreased with increasing age at first exposure $(\mathrm{P}=0.001$ for trend for brain cancer, $\mathrm{P}<0.001$ for trend for all cancers; table $7 \Downarrow$ ). For all solid cancers other than brain cancer, the IRR also tended to decrease with increasing age at first exposure $(\mathrm{P}=0.06$ for trend). Despite these reductions, the IRR remained significantly increased in the oldest group at first exposure, for brain cancers, all cancers combined, and all solid cancers other than brain cancer. For lymphoid and haematopoietic cancers other than leukaemias and myelodysplasias, the IRR also fell with increasing age at first exposure ( $\mathrm{P}=0.04$ for trend). For leukaemias and myelodysplasias, however, the IRR tended to increase with age at first exposure $(\mathrm{P}=0.06$ for trend). Nearly half of the exposed group had their first CT scan at ages 15-19 (table 2). Therefore, despite the IRR reduction with increasing age at first exposure for all cancers combined, over half the excess cancers (338 of 608) occurred among those first exposed at ages 15-19 years.

For brain cancer, leukaemias and myelodysplasias, other lymphoid and haematopoietic cancers, and all cancers combined, neither the IRR nor the EIR differed significantly between the sexes (web table D). However, for solid cancers other than brain cancer, the IRR was greater in female patients than in male patients (1.23 (95\% confidence interval 1.16 to 1.31$) v 1.14$ (1.07 to 1.22$), \mathrm{P}=0.07$ for difference); the EIR was also significantly greater in female patients than for male patients (7.59 (5.35 to 9.82) v 3.57 ( 1.76 to 5.37 ), $\mathrm{P}=0.006$ for difference). Socioeconomic status was only weakly related to CT scan exposure (table 1), and the effect of exposure did not differ significantly according to socioeconomic status (web table E). Information was not available for potential confounding factors such as alcohol, smoking, sun exposure, or for Down's syndrome or other markers of cancer susceptibility. However, because the CT related increase in cancer risk varied very little by socioeconomic status, it is unlikely that our results were substantially biased by confounding factors such as these.

\section{Cancer risk by site of CT scan}

For all cancers combined, the IRR in the exposed group versus the unexposed group was significantly increased $(\mathrm{P}<0.05)$ for 
every anatomical site of CT scan considered (fig $3 \Downarrow$ ). The IRRs differed according to the site of the CT scan $(\mathrm{P}<0.001$ for heterogeneity), with larger increases after $\mathrm{CT}$ scans of the chest (1.62) and abdomen or pelvis (1.61), and smaller increases after CT scans of the facial bones (1.14) and spine or neck (1.13).

For some CT sites, the IRR also varied between different types of cancer $(\mathrm{P}<0.001$ for heterogeneity after scans of head or brain; $\mathrm{P}=0.02$ after scans of abdomen or pelvis). After CT scans of the brain, the largest IRR was for brain cancer $(2.44,95 \%$ confidence interval 2.12 to 2.81 ), although there were also significant $(\mathrm{P}<0.05)$ increases for melanoma, soft tissue cancers, thyroid cancer, and other solid cancers. After scans of the abdomen or pelvis, the largest IRR was for leukaemias and myelodysplasias (3.24, 2.17 to 4.84); there were also significant increases for soft tissue cancer, brain cancer, and all other solid cancers apart from melanoma and thyroid cancer. Web figure D shows corresponding results based on a five year lag period.

\section{Risks after exclusion of brain cancers after a CT scan of the brain}

Almost $60 \%$ of CT scans were of the brain (table 2), and some low grade cancers in the brain may have given rise to symptoms that were investigated several years before they were finally diagnosed (that is, the brain cancer may have caused the scan, rather than vice versa). To explore the extent to which our results might have been affected by such reverse causation, we repeated our main analyses excluding any brain cancers that occurred after a CT scan of the brain. For all cancers other than brain cancers following a brain CT, the increase in IRR with increasing number of CT scans was maintained (web figure E). The IRR for brain cancers after a scan to a site other than the brain remained raised (1.51 (95\% confidence interval 1.19 to 1.91), table 4) as did the IRRs for all solid cancers (1.20, 1.15 to 1.25$)$ and for all cancers $(1.20,1.15$ to 1.24$)$. The IRR for the remaining brain cancers tended to decrease with increasing time since first exposure, although the trend did not reach significance $(\mathrm{P}=0.06$ for trend, table 5). The trend with time since first exposure in the IRR for all cancers (except brain cancer after a brain $\mathrm{CT}$ ) was also not significant $(\mathrm{P}=0.30$ for trend, table 5). In any given period after exposure, there was no significant association between the IRR for all solid cancers (except brain cancer after a brain $\mathrm{CT}$ ) and the calendar year of first exposure $(\mathrm{P}=0.68$ for trend, web table $\mathrm{C})$. The reduction in IRR for all solid cancers (except brain cancer after a brain CT scan) with increasing age at exposure was highly significant $(\mathrm{P}=0.01$ for trend, table 7), but there was no significant trend in the EIR with increasing age at exposure $(\mathrm{P}=0.21$ for trend $)$.

\section{Approximate risks to date per unit dose}

Based on a one year lag period, the collective effective dose from all CT scans combined was about $3900 \mathrm{~Sv}$, and the average effective dose to all organs of the body was about $4.5 \mathrm{mSv}$ per scan. On the assumption that all the excess cancers, apart from brain cancers after CT scans of the brain, are attributable to CT scans, this suggests that each sievert of effective dose caused 0.125 cancers by 31 December 2007 (table $8 \Downarrow$ ) in an average follow-up period of 9.5 years. So far, one in every $1800 \mathrm{CT}$ scans has been followed by an excess cancer, with an excess rate ratio per $\mathrm{mSv}$ of 0.035 (95\% confidence interval 0.026 to 0.042). A similar calculation considering only brain cancers after a brain CT suggests a collective organ dose to the brain of 19800 Gy from an average brain dose of 40 mGy per brain scan. If CT scans had caused all the excess of brain cancer in this group, each Gy to the brain would have led to 0.006 brain cancers by the end of available follow-up (31 December 2007), one in 4000 brain scans would have led to a brain cancer, and the excess rate ratio of brain cancers per $\mathrm{mGy}$ to the brain would be 0.029 ( $95 \%$ confidence interval 0.023 to 0.037 ). The estimated collective dose to red bone marrow, based on a one year lag period, was $4000 \mathrm{~Gy}$, and the average estimated red bone marrow dose was $4.6 \mathrm{mGy}$ per scan. This suggests that each gray of radiation to the red bone marrow has led to 0.012 excess leukaemias or myelodysplasias to date, and that the excess rate ratio for leukaemias and myelodysplasias per mGy to the red bone marrow is 0.039 (95\% confidence interval 0.014 to 0.070 ). When these calculations were repeated for lag periods of five and 10 years, the collective doses were considerably lower, and the excess rate ratio per $\mathrm{mSv}$ was slightly reduced for all cancers except brain cancer following a brain scan, more reduced for brain cancer following a brain scan, and substantially reduced for leukaemias and myelodysplasias at a 10 year lag (table 8).

\section{Discussion}

Our study is the largest population based study to date of diagnostic medical radiation exposure. It also provides more information about low dose exposures than was available from the study of Japanese atomic bomb survivors. ${ }^{18} 19$ Our study shows that CT scans during childhood and adolescence are followed by an increase in cancer incidence for all cancers combined and for many individual types of cancer. We cannot, however, necessarily assume that all the excess cancers seen during the current period of follow-up were caused by CT scans, because scanning decisions are based on medical indications and are not allocated at random. Thus, we cannot rule out the possibility of reverse causation, whereby symptoms of precancerous conditions (including genetic conditions ${ }^{20}{ }^{35-37}$ ) or early symptoms of the cancer itself might themselves prompt a CT scan. Such reverse causation is most likely to be present for brain cancers following a brain CT, where low grade cancers could lead to symptoms prompting investigation several years before the eventual diagnosis of cancer. ${ }^{38}$ We have, therefore, repeated our main analyses excluding brain cancers occurring after a brain CT; this did not change the overall results substantially (tables 4, 5, and 7; web figure E). For most cancers other than brain cancer, the prediagnostic phase is unlikely to last more than one year in young people, and is very unlikely to last more than 10 years; therefore, reverse causation cannot explain all the cancer excess observed in this study.

Although the inference that CT scans cause most of the excess cancer in exposed people cannot be conclusively proven, it is supported by several observations:

- The increase in IRR with increasing number of CT scans (fig 2), even after excluding brain cancers following brain CTs (web figure E)

- The larger proportional increase in incidence rate (IRR) after exposures at younger ages (table 7), as seen in the Life Span Study of survivors of the Japanese atomic bombings and in other studies of cancer following exposures at larger average doses ${ }^{814}$ 17-20

- The larger absolute excess incidence rate (EIR) for solid cancers in female patients than in male patients (web table D), as seen in other studies ${ }^{20}$

- The correlation between the site of the CT scan and the site of cancer, with a large proportional increase in the incidence rate (IRR) for leukaemias and myelodysplasias following exposure to red bone marrow from CTs of the abdomen or pelvis (fig 3) 
- The increased risks per CT scan and per unit of radiation dose for all cancers (other than brain cancer after a brain scan), even when considering lag periods of five and 10 years (table 8 ).

\section{Strengths and limitations of the study}

The Medicare dataset captures all CT services funded by the Australian federal government. Some individuals in our cohort would have had eligible CT scans that we were not able to identify. These scans included most of those performed in state based tertiary hospitals (because these are not funded on a fee-for-service basis through Medicare) and any that took place abroad, or before or after the period included in our study (1985-2005), or when the individual was aged 20 years or more. Because of this, some individuals with a CT scan would have been classified as unexposed in our analyses, leading to a small downward bias in our estimates of the cancer risks from CT scans; this misclassification would also have had a greater effect on analyses based on the number of CT scans, than on comparisons between exposed and unexposed cohorts.

In this study, it was impossible to collect protocols and machine parameters for all the $866580 \mathrm{CT}$ scans and use them to estimate individual doses. Accordingly, we estimated average doses for red bone marrow and brain, based on collective organ doses, as measures of exposure - taking into account the site of CT, the individual's age, and the year the scan was performed.

Averaging in this way would reduce the effect of variations in individual doses from practice to practice. ${ }^{32}$ For all cancers combined (other than brain cancers following a brain CT) and for all cancers combined, we carried out a similar averaging process, but based on effective dose. Effective dose is a summary measure used in radiation protection when considering the likely detriment after exposure of different body organs to different doses. ${ }^{26}$ It represents roughly the whole body uniform dose that would give rise to the same detriment as the exposures observed in the population at risk. This measure is not ideal for risk assessment, and it is not designed to be specific for any individual, but it has been used in many epidemiological studies as an average measure of exposure. We plan to incorporate additional information about changes in CT scanners and protocols over time in Australia to improve our estimates of specific organ absorbed doses for each study patient by age, sex, and calendar year and type of CT.

Records of repeat scans (for example, because the patient moved) were not available, leading to some additional uncertainty in our estimates of dose. Fortunately, recent improvements in CT technology have reduced total scan times and led to motion artefacts being less likely. ${ }^{39}$ Any effect of repeat scans would therefore be greater for patients exposed in the early years after 1985, and this might partly explain the downward trend with calendar period in the risk of brain cancer after a brain scan (table 6, web figs B and C). However, this trend might also be due to lower doses following other recent improvements in technology and protocols. The aggregate effect of undocumented repeat exposures is likely to be small, but it would be expected to introduce a small upward bias into our estimates of cancer risks per unit of dose. It would not, however, add any bias in the absence of any true effect.

\section{Comparison with other studies}

For leukaemias and myelodysplasias, our estimate of the excess rate ratio per mGy was 0.039 (95\% confidence interval 0.014 to 0.070 ), based on a one year lag (table 8). This is similar to the corresponding estimate reported for young people exposed to $\mathrm{CT}$ scans in the UK $(0.036,95 \%$ confidence interval 0.005 to 0.120 ; table $9 \Downarrow$ ). ${ }^{12}$ For leukaemias, estimates of the excess rate ratio per $m G y$ derived in a roughly comparable way (that is, excluding myelodysplasias and the first five years of follow-up) were also similar between the present study $(0.035$ (95\% confidence interval 0.000 to 0.077$)$ ) and the Life Span Study of atomic bomb survivors $(0.045$ (0.016 to 0.188$)$ ), based on a five year lag period; tables 8 and 9). ${ }^{12} 1840$

For brain cancer, the estimates of the excess rate ratios per mGy from all three studies were also compatible (present study 0.021 (95\% confidence interval 0.014 to 0.029$) v$ UK study $^{12} 0.023$ ( 0.010 to 0.049 ), based on five year lag period; present study 0.015 (0.007 to 0.026) $v$ Life Span Study ${ }^{40} 0.006$ (0.000 to $0.064)$, based on 10 year lag period). Despite the similarity of risk estimates in the various studies, it is possible that some of the excess brain cancer seen in our study in the first few years after exposure was due to reverse causation, and the diminishing risk with increasing time since exposure (table 5) is consistent with such an explanation. However, the very high IRR for brain cancer during years 1-4 after first exposure could also be due to ionising radiation having its greatest early effect on children with high genetic susceptibility to radiogenic brain cancer. ${ }^{20} 363741$ On this model, brain cancer EIR would decline after 10 years of follow-up because people with the greatest susceptibility, and exposed to radiation at younger ages, had already been affected. If the carcinogenic effect of low dose radiation is greater for the minority of people who are genetically susceptible, this will have important implications for future standards of radiation protection, as well as for liability and compensation.

Our study provides new and direct evidence for increases in cancers other than brain cancers and leukaemias and myelodysplasias following exposure to ionising radiation from CT scans. Risk was increased for many specific types of cancers (affecting the digestive organs, skin (melanoma), soft tissue, female genital organs, urinary tract, thyroid, Hodgkin's lymphoma, and other lymphoid cancers (C84-90); table 4). The increase in risk was present throughout the range of ages at exposure considered in our study (table 7), and was already apparent in the period 1-4 years after first exposure (table 5). In our study, the estimated excess rate ratio per $\mathrm{mSv}$ for all cancers except brain cancer after a brain scan was 0.035 (95\% confidence interval 0.026 to 0.042 ), based on a one year lag period (tables 8 and 9). No comparable estimate is at present available from the UK study. From our study, we estimated the excess rate ratio to be 0.027 ( 0.017 to 0.037 ) per $\mathrm{mSv}$ (effective dose) for all solid cancers other than brain cancer, based on a 10 year lag period (table 9$)$. This value was higher than the corresponding estimate for the Life Span Study (0.003 (0.002 to 0.006), based on colon dose; Mark Little (National Cancer Institute), personal communication, March 2013). This comparison is, however, subject to many uncertainties.

For lag periods of one, five, and 10 years, the incidence rate for all cancers combined increased by $24 \%, 21 \%$, and $18 \%$, respectively, in the $\mathrm{CT}$ exposed group compared with the unexposed group (table 3 ). The estimated numbers of excess cancers attributable to CT scans for these three lag periods were 608,402 , and 209, respectively. These excesses were, at most, $1 \%$ of the 60674 cancers observed to date in this cohort of 10.9 million people. After excluding brain cancers following a brain scan, we found that by 31 December 2007, there was one excess cancer for every $1800 \mathrm{CT}$ scans based on a one year lag period, and one excess cancer for every $2200 \mathrm{CT}$ scans based on a 10 year lag period (table 8). 
By the end of our current follow-up, the oldest study members were only in their early 40s, when many cancers are still uncommon. Yet the absolute excess incidence rate (EIR) for all solid cancers other than brain cancer after a brain CT increased with time since exposure (table $5 ; \mathrm{P}=0.01$ for trend), suggesting that the number of excess cancers among the exposed cohort is likely to rise in future years, increasing the eventual lifetime risk. Our results are also generally consistent with the linear no threshold theory (that is, there is no threshold dose below which there is a zero risk). Thus, our findings justify concerns about risks from $\mathrm{CT}$ scan exposures in childhood and adolescence, ${ }^{14101142}$ and also support concerns about the likely risks from $\mathrm{CT}$ exposures in adult life.

\section{Conclusions and policy implications}

Practitioners will increasingly need to weigh the undoubted benefits of CT scans in clinical practice against the potential risks to justify each CT scan decision. ${ }^{11}{ }^{43-46}$ Fortunately, many radiologists are now aware of the risks, and technological advances have already allowed CT scan doses to be reduced below those used in earlier decades. ${ }^{12}{ }^{13}$ However, decision tools to objectively assess the need for $\mathrm{CT}^{47}$ are still not used routinely-for example, minor head trauma or suspected appendicitis are often managed using CT, rather than by observation, ultrasound, or magnetic resonance imaging. ${ }^{48}$ Imaging for head trauma still accounts for most CT scans in children. ${ }^{48}{ }^{49}$ It is timely to alert the wider community, as well as the non-radiologist physicians who order most CT scans, to the potential risks. All parties, including patients and families, ${ }^{50}$ need to work together to ensure that CT scans are limited to situations where there is a definite clinical indication, and where every scan is optimised to provide a diagnostic CT image at the lowest possible radiation dose.

We thank Bruce Armstrong, D'Arcy Holman, and Richard Peto for epidemiological advice; and John Heggie, Luke Wilkinson, and Paul Einsiedel for advice on dosimetry. Officials of the Department of Health and Ageing, Medicare, the Australian Institute of Health and Welfare, Chief Health Officers, and registrars of state and territory cancer registries provided access to data.

Contributors: JDM conceived, designed, and managed the study; obtained funding; carried out most statistical analyses; drafted and finalised the manuscript; and was responsible for data integrity and guarantor of the study. AVF extracted data for analysis, assisted with data presentation, maintained ethical approvals, and reviewed the manuscript. ZB advised on CT scan classifications, use, and dosimetry; and revised and reviewed the manuscript. MWB extracted de-identified data, advised on data integrity and interpretation, and reviewed the manuscript. SKG advised on CT procedures and coding in paediatric practice, and reviewed the manuscript. GBB advised on the study design, statistical methods, data analysis, and interpretation; and reviewed the manuscript. GGG advised on the cancer nomenclature and epidemiology, study design, data analysis and interpretation; and reviewed the manuscript. ABW advised on medical radiation and radiation physics, provided guidance on dose estimation, and reviewed the manuscript. PRA and TAG were involved in the linkage of Medicare records with cancer and mortality data, and reviewed manuscript. PM provided a revised person years Stata program and reviewed the manuscript. TMC provided guidance regarding radiation dose estimation, Medicare descriptors, and CT classification; and reviewed the manuscript. JGD advised on study design and analysis, and reviewed the manuscript. ACB designed and implemented the database and data extraction procedures, and reviewed the manuscript. SCD advised on radiation epidemiology, statistical methods, study design, data analysis and interpretation, and data presentation (tables, figures, and formatting), and made substantial contributions to the manuscript.

Funding: This research was funded by the Australian government via the National Health and Medical Research Council, and supported by in-kind contributions of people funded by the Cancer Research Campaign UK or employed by other agencies. The funding bodies had no role in study design, data analysis, or reporting; government agencies contributed to data collection and data linkage, but did not control data analysis, interpretation, or writing of the report. The corresponding author had full access to all data in the study, and had ultimate responsibility for data integrity, statistical analysis, and the decision to submit for publication.

Competing interests: All authors have completed the ICMJE uniform disclosure form at www.icmje.org/coi_disclosure.pdf and declare: support from the Australian government (via the National Health and Medical Research Council, salary support from the Cancer Research Campaign UK and other agencies) for the submitted work; no financial relationships with any organisations that might have an interest in the submitted work in the previous three years; no other relationships or activities that could appear to have influenced the submitted work.

Ethical approval: This study was approved by the human research ethics committee of the University of Melbourne (ethics ID 0723066), and by ethics committees, data custodians, and cancer registrars of the Australian Government Department of Health and Ageing, Medicare, Australian Institute of Health and Welfare, and all states and territories of Australia.

Data sharing: The data used for this study were provided on the basis that they would be used in accordance with the study protocol, and the approvals granted by the University of Melbourne and by ethics committees and data custodians of the Australian government and all state and territory governments.

1 Brenner DJ, Elliston CD, Hall EJ, Berdon WE. Estimated risks of radiation-induced fatal cancer from pediatric CT. AJR Am J Roentgenol 2001;176:289-96.

2 Berrington de González A, Darby S. Risk of cancer from diagnostic X-rays: estimates for the UK and 14 other countries. Lancet 2004;363:345-51.

3 Brenner DJ, Hall EJ. Computed tomography-an increasing source of radiation exposure. N Engl J Med 2007;357:2277-84

4 Berrington de González A, Mahesh M, Kim KP, Bhargavan M, Lewis R, Mettler F, et al. Projected cancer risks from computed tomographic scans performed in the United States in 2007. Arch Intern Med 2009:169:2071-7.

5 Fazel R, Krumholz HM, Wang YF, Ross JS, Chen J, Ting HH, et al. Exposure to low-dose ionizing radiation from medical imaging procedures. N Engl J Med 2009;361:849-57.

6 Lauer MS. Elements of danger-the case of medical imaging. N Engl J Med 2009;361:841-3.

7 Smith-Bindman R. Is computed tomography safe? N Engl J Med 2010;363:1-4.

8 United Nations Scientific Committee on the Effects of Atomic Radiation. UNSCEAR 2008 report to the General Assembly. United Nations, 2010.

9 Brady Z, Cain TM, Johnston PN. Paediatric CT imaging trends in Australia. J Med Imaging Radiat Oncol 2011;55:132-42.

10 Pearce MS. Patterns in paediatric CT use: an international and epidemiological perspective. J Med Imaging Radiat Oncol 2011;55:107-9.

11 Brady Z, Cain TM, Johnston PN. Justifying referrals for paediatric CT. Med J Aust 2012:197:95-8.

12 Pearce MS, Salotti JA, Little MP, McHugh K, Lee C, Kim KP, et al. Radiation exposure from CT scans in childhood and subsequent risk of leukaemia and brain tumours: a retrospective cohort study. Lancet 2012;380:499-505.

13 Kim KP, Berrington de González A, Pearce MS, Salotti JA, Parker L, McHugh K, et al. Development of a database of organ doses for paediatric and young adult CT scans in the United Kingdom. Radiat Prot Dosimetry 2012;150:415-26.

14 World Health Organization, International Agency for Research on Cancer. Ionizing radiation, part 1:x-and gamma (Y)-radiation, and neutrons. IARC Monogr Eval Carcinog Risks Hum 2000;75:1-492.

15 Brenner DJ, Doll R, Goodhead DT, Hall EJ, Land CE, Little JB, et al. Cancer risks attributable to low doses of ionizing radiation: assessing what we really know. Proc Nat Acad Sci U S A 2003;100:13761-6.

16 Linet MS, Kim KP, Rajaraman P. Children's exposure to diagnostic medical radiation and cancer risk: epidemiologic and dosimetric considerations. Pediatr Radiol 2009;39:S4-26.

17 Shimizu Y, Kato H, Schull WJ. Studies of the mortality of A-bomb survivors: 9 Mortality, 1950-1985. Part 2. Cancer mortality based on the recently revised doses (DS86). Radiat Res 1990;121:120-41.

18 Preston DL, Kusumi S, Tomonaga M, Izumi S, Ron E, Kuramoto A, et al. Cancer incidence in atomic bomb survivors. Part III: leukemia, lymphoma and multiple myeloma, 1950-1987. Radiat Res 1994;137:S68-97.

19 Thompson DE, Mabuchi K, Ron E, Soda M, Tokunaga M, Ochikubo S, et al. Cancer incidence in atomic bomb survivors. Part II: solid tumors, 1958-1987. Radiat Res 1994;137:S17-67.

20 National Research Council, Committee to Assess Health Risks from Exposure to Low Levels of lonizing Radiation. Health risks from exposure to low levels of ionizing radiation: BEIR VII phase 2. National Academies Press, 2006. 


\section{What is already known on this topic}

CT scanning rates have risen substantially since the 1980s. Although large doses of ionising radiation are known to cause cancer, there is uncertainty about the risks following the lower doses from CT scans (5-50 mGy per organ)

A recent study of 180000 young people exposed to CT scans in the United Kingdom found an increasing risk of leukaemia and brain cancer with increasing radiation dose

\section{What this study adds}

Among 680000 Australians exposed to a CT scan when aged 0-19 years, cancer incidence was increased by $24 \%$ ( $95 \%$ confidence interval $20 \%$ to $29 \%$ ) compared with the incidence in over 10 million unexposed people. The proportional increase in risk was evident at short intervals after exposure and was greater for persons exposed at younger ages

By 31 December 2007, with an average follow-up of 9.5 years after exposure, the absolute excess cancer incidence rate was 9.38 per 100000 person years at risk

Incidence rates were increased for most individual types of solid cancer, and for leukaemias, myelodysplasias, and some other lymphoid cancers

21 Cardis E, Vrijheid M, Blettner M, Gilbert E, Hakama M, Hill C, et al. Risk of cancer after low doses of ionising radiation: retrospective cohort study in 15 countries. BMJ 2005;331:77-80

22 National Council on Radiation Protection and Measurements. Uncertainties in the estimates of radiation risks and probability of disease causation. Report no 171. NCRP, 2012.

23 Hendee WR, O'Connor MK. Radiation risks of medical imaging: separating fact from fantasy. Radiology 2012;264:312-21.

24 Socio-economic indexes for areas (SEIFA). Technical paper. Cat no 2039.0.55.001. 2006. www.abs.gov.au/AUSSTATS/abs@.nsf/DetailsPage/2039.0.55.0012006?OpenDocument.

25 Plummer M. Improved estimates of floating absolute risk. Stat Med 2004;23:93-104.

26 International Commission on Radiological Protection. The 1990 Recommendations of the International Commission on Radiological Protection. ICRP Publication 60. Ann ICRP 1990;21:1-201.

27 Shrimpton PC, Jones DG, Hillier M, Wall BF, Le Heron JC, Faulkner K. Survey of CT practice in the UK. Part 2-dosimetric aspects. NRPB-R249. National Radiological Protection Board, 1991.

28 Huda W, Atherton JV, Ware DE, Cumming WA. An approach for the estimation of effective radiation dose at CT in pediatric patients. Radiology 1997;203:417-22.

29 McLean D, Malitz N, Lewis S. Survey of effective dose levels from typical paediatric CT protocols. Australas Radiol 2003:47:135-42.

30 Shrimpton PC, Hillier MC, Lewis MA, Dunn M. Doses from computed tomography (CT) examinations in the UK-2003 review. NRPB-W67. National Radiological Protection Board, 2005.

31 Galanski M, Nagel HD, Stamm G. Paediatric CT exposure practice in the Federal Republic of Germany. Results of a nation-wide survey in 2005/06. 2006. www.mh-hannover.de/ fileadmin/kliniken/diagnostische_radiologie/download/Report_German_Paed-CT-Survey_ 2005_06.pdf.

32 Moss M, McLean D. Paediatric and adult computed tomography practice and patient dose in Australia. Australas Radiol 2006;50:33-40.

33 Brady Z. Radiation doses and risks from paediatric computed tomography [Thesis]. Royal Melbourne Institute of Technology University, 2012.

34 Huda W, Ogden KM. Computing effective doses to pediatric patients in Computed Tomography. Pediatr Radiol 2008;38:415-23.

35 Eden T. Aetiology of childhood leukaemia. Cancer Treat Rev 2010;36:286-97.

36 Gatti RA, Boder E, Vinters HV, Sparkes RS, Norman A, Lange K. Ataxia-telangiectasia: an interdisciplinary approach to pathogenesis. Medicine 1991;70:99-117.

37 Lee $\mathrm{Y}$, Miller HL, Jensen P, Hernan R, Connelly M, Wetmore C, et al. A molecular fingerprint for medulloblastoma. Cancer Res 2003;63:5428-37.
38 Singh G, Driever PH, Sander JW. Cancer risk in people with epilepsy: the role of antiepileptic drugs. Brain 2005;128:7-17.

39 White KS. Helical/spiral CT scanning: a pediatric radiology perspective. Pediatr Radiol 1996;26:5-14.

40 Preston DL, Ron E, Tokuoka S, Funamoto S, Nishi N, Soda M, et al. Solid cancer incidence in atomic bomb survivors: 1958-1998. Radiat Res 2007;168:1-64

41 Olsen JH, Hahnemann JM, Børresen-Dale AL, Brøndum-Nielsen K, Hammarström L, Kleinerman $\mathrm{R}$, et al. Cancer in patients with ataxia-telangiectasia and in their relatives in the Nordic countries. J Natl Cancer Inst 2001:93:121-7.

42 Frush DP, Donnelly LF, Rosen NS. Computed tomography and radiation risks: what pediatric health care providers should know. Pediatrics 2003;112:951-7.

43 Frush DP. Responsible use of CT. Radiology 2003;229:289-91.

44 Remedios DJ, Seymour B. Making the best use of clinical radiology. BMJ 2011;342:d1951.

45 Brenner DJ, Hall EJ. Cancer risks from CT scans: now we have data, what next? Radiology 2012;265:330-1.

46 Einstein AJ. Beyond the bombs: cancer risks of low-dose medical radiation. Lancet 2012;380:455-7.

47 Osmond MH, Klassen TP, Wells GA, Correll R, Jarvis A, Joubert G, et al. CATCH: a clinical decision rule for the use of computed tomography in children with minor head injury. CMAJ 2010;182:341-8.

48 Nigrovic LE, Schunk JE, Foerster A, Cooper A, Miskin M, Atabaki SM, et al. The effect of observation on cranial computed tomography utilization for children after blunt head trauma. Pediatrics 2011;127:1067-73.

49 Jackson D, Ditchfield M, Goergen SK. Trans-Tasman CT dose audit. Asian Oceanian Congress of Radiology, Royal Australian and New Zealand College of Radiologists Annual Scientific Meeting, 2 September 2012. Wiley, 2012.

50 Picano E. Informed consent and communication of risk from radiological and nuclear medicine examinations: how to escape from a communication inferno. $B M\lrcorner$ 2004;329:849-51.

\section{Cite this as: BMJ 2013;346:f2360}

This is an Open Access article distributed in accordance with the Creative Commons Attribution Non Commercial (CC BY-NC 3.0) license, which permits others to distribute, remix, adapt, build upon this work non-commercially, and license their derivative works on different terms, provided the original work is properly cited and the use is non-commercial. See: http://creativecommons.org/licenses/by-nc/3.0/. 


\section{Tables}

\section{Table 1 | Characteristics of study population by final exposure status, based on a one year lag period}

\begin{tabular}{|c|c|c|}
\hline Characteristic & No (\%) of people exposed ${ }^{*}$ & Total no of people in study \\
\hline \multicolumn{3}{|l|}{ Sex } \\
\hline Male & $357119(6.4)$ & 5563105 \\
\hline Female & $323092(6.0)$ & 5376575 \\
\hline \multicolumn{3}{|l|}{ Age at entry to study (years) } \\
\hline $0-4$ & $450346(6.8)$ & 6652654 \\
\hline $5-9$ & $120957(9.0)$ & 1339527 \\
\hline $10-14$ & $80731(5.4)$ & 1489524 \\
\hline $15-19$ & $28177(1.9)$ & 1457975 \\
\hline \multicolumn{3}{|l|}{ Calendar year of entry to study } \\
\hline $1985-89$ & $526488(8.6)$ & 6156422 \\
\hline $1990-94$ & $99466(6.5)$ & 1539278 \\
\hline $1995-99$ & $40931(2.8)$ & 1467602 \\
\hline $2000-05$ & $13326(0.8)$ & 1776378 \\
\hline \multicolumn{3}{|l|}{ Socioeconomic group } \\
\hline 1 (lowest status) & $82332(5.3)$ & 1557545 \\
\hline 2 & $97236(6.2)$ & 1556448 \\
\hline 3 & $95547(6.1)$ & 1557331 \\
\hline 4 & $101154(6.5)$ & 1556311 \\
\hline 5 & $103454(6.6)$ & 1558887 \\
\hline 6 & $102449(6.6)$ & 1557562 \\
\hline 7 (highest status) & $97392(6.3)$ & 1554273 \\
\hline Unknown status & $647(1.6)$ & 41323 \\
\hline Total no of people in study & $680211(6.2) \dagger$ & 10939680 \\
\hline
\end{tabular}

*Exposure status at end of study. All study members were classified as unexposed on entry to the study. Those exposed to a CT scan continued to be classified as unexposed for the duration of the lag period (taken to be one year here and in most analyses, but five or 10 years in some analyses). They were then transferred to the exposed group, provided that the date of transfer was before the date of exit from the study (fig 1).

†The total no of CT scans received by these individuals at least one year before date of exit was 866580 . 
Table 2| Characteristics of cohort members whose final status was exposed, based on a one year lag period

\begin{tabular}{|c|c|}
\hline Characteristic & No (\%) of people exposed \\
\hline \multicolumn{2}{|l|}{ Sex } \\
\hline Male & $357119(52.5)$ \\
\hline Female & $323092(47.5)$ \\
\hline \multicolumn{2}{|l|}{ Age at first CT scan (years) } \\
\hline $0-4$ & $42798(6.3)$ \\
\hline $5-9$ & $104618(15.4)$ \\
\hline $10-14$ & 202420 (29.8) \\
\hline $15-19$ & 330375 (48.5) \\
\hline \multicolumn{2}{|l|}{ Calendar year of first CT scan } \\
\hline $1985-89$ & $95249(14.0)$ \\
\hline $1990-94$ & $133528(19.6)$ \\
\hline 1995-99 & $184463(27.1)$ \\
\hline 2000-05 & 266971 (39.3) \\
\hline \multicolumn{2}{|l|}{ Final no of CT scans } \\
\hline 1 & $557877(82.0)$ \\
\hline 2 & $86109(12.7)$ \\
\hline 3 & $23740(3.5)$ \\
\hline 4 & $6763(1.0)$ \\
\hline$\geq 5$ & $5722(0.8)$ \\
\hline \multicolumn{2}{|l|}{ Site of first CT scan } \\
\hline Brain $^{*}$ & $404105(59.4)$ \\
\hline Facial bones & $89133(13.1)$ \\
\hline Chest & $11381(1.7)$ \\
\hline Extremities & $64940(9.5)$ \\
\hline Abdomen or pelvis $\dagger$ & $33870(5.0)$ \\
\hline Spine or neck & $58677(8.6)$ \\
\hline Other or unknown & $18105(2.7)$ \\
\hline Total no (\%) of people exposed & $680211(100.0)$ \\
\hline
\end{tabular}

*Includes brain in combination with other sites such as the chest. †Includes combined scans of the chest, abdomen, and pelvis. 
Table 3| Number of cancers of all types and incidence rate ratios (IRR), exposed $\mathbf{v}$ unexposed, for various lag periods

\begin{tabular}{|c|c|c|c|}
\hline & \multicolumn{3}{|c|}{ Lag period } \\
\hline & 1 year & 5 years & 10 years \\
\hline \multicolumn{4}{|l|}{ Exposed group } \\
\hline Observed no of cancers & 3150 & 2365 & 1405 \\
\hline No of person years & 6486548 & 3971641 & 1808883 \\
\hline Mean years of follow-up & 9.5 & 7.3 & 5.5 \\
\hline \multicolumn{4}{|l|}{ Unexposed group } \\
\hline Observed no of cancers & 57524 & 58309 & 59269 \\
\hline No of person years & 177191342 & 179706249 & 181869007 \\
\hline Mean years of follow-up & 17.3 & 17.3 & 17.1 \\
\hline Expected no of cancers in exposed group ${ }^{*}$ & 2542 & 1963 & 1196 \\
\hline No of excess cancers in exposed group* & 608 & 402 & 209 \\
\hline IRR (95\% Cl; exposed $v$ unexposed) & $1.24(1.20$ to 1.29$)$ & $1.21(1.16$ to 1.26$)$ & $1.18(1.11$ to 1.24$)$ \\
\hline$x^{2}(1 \mathrm{df})$ for departure of IRR from unity & 129.1 & 74.4 & 33.8 \\
\hline$P$ for departure of IRR from unity & $P<0.001$ & $P<0.001$ & $P<0.001$ \\
\hline
\end{tabular}

${ }^{*}$ Calculated from rates in unexposed group after stratification for age, sex, and year of birth. 


\begin{tabular}{|c|c|c|c|c|}
\hline Cancer type (ICD-10 code)* & $\begin{array}{l}\text { Observed no of } \\
\text { cancers }\end{array}$ & $\begin{array}{l}\text { IRR (95\% Cl; exposed } v \\
\text { unexposed) } \dagger\end{array}$ & $\begin{array}{l}\text { No of excess } \\
\text { cancers } \dagger\end{array}$ & $\begin{array}{c}\text { EIR }(95 \% \mathrm{Cl}) \text { per } 100000 \text { person } \\
\text { years } \dagger\end{array}$ \\
\hline All solid cancers (C00-80) & 2507 & $1.25(1.20$ to 1.31$)$ & 503.2 & 7.76 (6.24 to 9.27$)$ \\
\hline Mouth and pharynx (C00-14) & 87 & $1.08(0.87$ to 1.35$)$ & 6.3 & $0.10(-0.18$ to 0.38$)$ \\
\hline Digestive organs (C15-26) & 149 & $1.29(1.09$ to 1.52$)$ & 32.8 & 0.51 (0.14 to 0.87$)$ \\
\hline Respiratory organs (C30-39) & 48 & $1.31(0.97$ to 1.76$)$ & 11.5 & $0.18(-0.03$ to 0.39$)$ \\
\hline Bone (C40-41) & 72 & $1.15(0.91$ to 1.47$)$ & 9.7 & $0.15(-0.11$ to 0.41$)$ \\
\hline Melanoma (C43-44) & 809 & $1.12(1.04$ to 1.20$)$ & 86.8 & 1.34 (0.48 to 2.20$)$ \\
\hline Soft tissue (C45-49) & 119 & $1.78(1.47$ to 2.16$)$ & 51.7 & 0.80 (0.47 to 1.13$)$ \\
\hline Breast (C50) & 145 & $0.99(0.83$ to 1.17$)$ & -1.8 & $-0.03(-0.39$ to 0.34$)$ \\
\hline Female genital organs (C51-58) & 181 & $1.28(1.10$ to 1.49$)$ & 40.1 & 0.62 (0.21 to 1.02$)$ \\
\hline Male genital organs (C60-63) & 275 & 1.08 (0.95 to 1.22$)$ & 19.9 & $0.31(-0.19$ to 0.81$)$ \\
\hline Urinary tract (C64-C68) & 51 & $1.33(1.00$ to 1.78$)$ & 13.3 & $0.21(-0.01$ to 0.42$)$ \\
\hline Brain (C69-72) & 283 & $2.13(1.88$ to 2.41$)$ & 147.3 & 2.27 (1.76 to 2.78$)$ \\
\hline Brain after brain CT scan & 210 & 2.44 (2.12 to 2.81$)$ & 122.7 & 2.97 (2.28 to 3.66$)$ \\
\hline Brain after other CT scan & 73 & 1.51 (1.19 to 1.91$)$ & 24.6 & 1.05 (0.33 to 1.76$)$ \\
\hline Thyroid (C73-75) & 258 & $1.40(1.23$ to 1.59$)$ & 71.4 & $1.10(0.62$ to 1.59$)$ \\
\hline III defined and unspecified sites (C76-80) & 30 & $1.85(1.27$ to 2.71$)$ & 14.0 & 0.22 (0.05 to 0.38$)$ \\
\hline $\begin{array}{l}\text { All lymphoid and haematopoietic } \\
\text { cancers (C81-96, D45-46, D47.1, D47.3) }\end{array}$ & 643 & 1.19 (1.10 to 1.29$)$ & 105.3 & 1.62 (0.86 to 2.39$)$ \\
\hline Hodgkin's lymphoma (C81) & 228 & 1.15 (1.01 to 1.32$)$ & 30.4 & $0.47(0.01$ to 0.92$)$ \\
\hline Other lymphomas (C82-83) & 104 & $1.01(0.82$ to 1.23$)$ & 0.2 & $0.00(-0.30$ to 0.31$)$ \\
\hline Other lymphoid cancers (C84-90) & 65 & $1.70(1.31$ to 2.20$)$ & 26.8 & $0.41(0.17$ to 0.66$)$ \\
\hline $\begin{array}{l}\text { Leukaemias and myelodysplasias (C91-96, } \\
\text { D45-46, D47.1, D47.3) }\end{array}$ & 246 & $1.23(1.08$ to 1.41$)$ & 47.8 & $0.74(0.26$ to 1.21$)$ \\
\hline Leukaemias (C91-96) & 211 & $1.19(1.03$ to 1.37$)$ & 34.3 & 0.53 (0.09 to 0.97$)$ \\
\hline Lymphoid leukaemia (C91) & 84 & $0.96(0.77$ to 1.20$)$ & -2.1 & $-0.03(-0.31$ to 0.24$)$ \\
\hline Myeloid and other leukaemias (C92-96) & 127 & $1.41(1.18$ to 1.70$)$ & 36.4 & $0.56(0.22$ to 0.90$)$ \\
\hline Myelodysplasia (D45-D46, D47.1, D47.3) & 35 & $1.60(1.13$ to 2.27$)$ & 13.5 & 0.21 (0.03 to 0.39$)$ \\
\hline All cancers & 3150 & $1.24(1.20$ to 1.29$)$ & 608.4 & 9.38 (7.68 to 11.08$)$ \\
\hline $\begin{array}{l}\text { All solid cancers, except brain cancer } \\
\text { after brain CT }\end{array}$ & 2297 & $1.20(1.15$ to 1.25$)$ & 380.4 & 5.86 (4.35 to 7.38$)$ \\
\hline $\begin{array}{l}\text { All cancers, except brain cancer after } \\
\text { brain CT }\end{array}$ & 2940 & $1.20(1.15$ to 1.24$)$ & 485.7 & 7.49 (5.79 to 9.18$)$ \\
\hline
\end{tabular}

Web tables $A$ and $B$ show results based on lag periods of five and 10 years, respectively. IRR=incidence rate ratio, exposed $v$ unexposed; EIR=absolute excess incidence rate compared with rates in unexposed group.

*ICD codes most accurately reflect the cancer types in tables 4-9. The names used referred to the commonest cancer types in each rubric (for example, rubric C69-72 referred to eye cancer and other cancers of the central nervous system as well as brain cancer); rubric C73-75 referred to thyroid cancer and other endocrine cancers). C97 was not included in this table, because it was not used for cancer incidence registrations.

†IRR, EIR, and number of excess cancers calculated after stratification for age, sex, and year of birth. 


\begin{tabular}{|c|c|c|c|c|c|}
\hline \multirow[b]{2}{*}{ Type of cancer } & \multicolumn{4}{|c|}{ No of years since first exposure } & \multirow[b]{2}{*}{ P for treno } \\
\hline & $1-4$ & $5-9$ & $10-14$ & $\geq 15$ & \\
\hline \multicolumn{6}{|c|}{ Observed no of cancers in exposed group, IRR $(95 \% \mathrm{Cl})^{*}$} \\
\hline Brain cancer & $121,2.82(2.34$ to 3.39$)$ & $83,2.03$ (1.62 to 2.54$)$ & $46,1.50$ (1.11 to 2.01$)$ & $33,1.67$ (1.18 to 2.36$)$ & $<0.001$ \\
\hline After brain $\mathrm{CT}$ & $87,3.24$ (2.61 to 4.02$)$ & $62,2.42$ (1.88 to 3.12$)$ & $36,1.80(1.29$ to 2.51$)$ & $25,1.74$ (1.17 to 2.59$)$ & $<0.001$ \\
\hline After other CT & $34,2.08$ (1.47 to 2.92$)$ & $21,1.34$ (0.87 to 2.07$)$ & $10,0.93(0.50$ to 1.73$)$ & $8,1.47(0.73$ to 2.94$)$ & 0.06 \\
\hline $\begin{array}{l}\text { All solid cancers except brain } \\
\text { cancer }\end{array}$ & $438,1.23(1.12$ to 1.35$)$ & $646,1.17$ (1.09 to 1.27$)$ & $611,1.14(1.05$ to 1.24$)$ & $529,1.24(1.14$ to 1.35$)$ & 0.88 \\
\hline $\begin{array}{l}\text { Leukaemias and } \\
\text { myelodysplasias }\end{array}$ & $95,1.20$ (0.98 to 1.48$)$ & $85,1.40(1.13$ to 1.74$)$ & $39,1.07$ (0.78 to 1.47$)$ & $27,1.19$ (0.81 to 1.75$)$ & 0.82 \\
\hline $\begin{array}{l}\text { Other lymphoid and } \\
\text { haematopoietic cancers }\end{array}$ & $131,1.25$ (1.05 to 1.49$)$ & $146,1.27$ (1.08 to 1.50$)$ & $76,1.00(0.79$ to 1.25$)$ & $44,1.02(0.76$ to 1.38$)$ & 0.44 \\
\hline All cancers & $785,1.35$ (1.25 to 1.45$)$ & $960,1.25$ (1.17 to 1.34$)$ & $772,1.14$ (1.06 to 1.22$)$ & $633,1.24$ (1.14 to 1.34$)$ & 0.009 \\
\hline $\begin{array}{l}\text { All solid cancers, except brain } \\
\text { cancer after brain CT }\end{array}$ & $472,1.26$ (1.16 to 1.38$)$ & $667,1.18$ (1.09 to 1.27$)$ & $621,1.14$ (1.05 to 1.23$)$ & $537,1.24$ (1.14 to 1.36$)$ & 0.72 \\
\hline $\begin{array}{l}\text { All cancers, except brain } \\
\text { cancer after brain CT }\end{array}$ & $698,1.25$ (1.16 to 1.35$)$ & $898,1.21$ (1.13 to 1.29$)$ & $736,1.12(1.04$ to 1.20$)$ & $608,1.22$ (1.13 to 1.32$)$ & 0.30 \\
\hline \multicolumn{6}{|c|}{ No of excess cancers in exposed group, EIR per 100000 person years $(95 \% \mathrm{Cl})^{\star}$} \\
\hline Brain cancer & $77.6,3.09$ (2.23 to 3.94$)$ & $41.4,1.91$ (1.09 to 2.74$)$ & $15.1,1.25$ (0.15 to 2.34$)$ & $13.2,2.21$ (0.32 to 4.10$)$ & 0.03 \\
\hline After brain $\mathrm{CT}$ & $60.1,3.97$ (2.76 to 5.18$)$ & $36.1,2.66$ (1.52 to 3.79$)$ & $15.9,1.95$ (0.51 to 3.38$)$ & $10.6,2.40(0.19$ to 4.60$)$ & 0.05 \\
\hline After other CT & $17.6,1.75(0.61$ to 2.89$)$ & $5.3,0.66(-0.46$ to 1.78$)$ & $-0.8,-0.20(-1.77$ to 1.37$)$ & $2.5,1.67(-1.98$ to 5.32$)$ & 0.11 \\
\hline $\begin{array}{l}\text { All solid cancers except brain } \\
\text { cancer }\end{array}$ & $81.2,3.23$ (1.60 to 4.86$)$ & $95.3,4.40$ (2.10 to 6.71$)$ & $76.3,6.29$ (2.30 to 10.29$)$ & $103.0,17.29$ (9.72 to 24.86$)$ & 0.01 \\
\hline $\begin{array}{l}\text { Leukaemias and } \\
\text { myelodysplasias }\end{array}$ & $16.4,0.65(-0.11$ to 1.41$)$ & $24.5,1.13(0.30$ to 1.97$)$ & $2.6,0.21(-0.80$ to 1.22$)$ & $4.3,0.73(-0.98$ to 2.44$)$ & 0.78 \\
\hline $\begin{array}{l}\text { Other lymphoid and } \\
\text { haematopoietic cancers }\end{array}$ & $25.9,1.03$ (0.14 to 1.92$)$ & $31.2,1.44$ (0.35 to 2.54$)$ & $-0.5,-0.04(-1.45$ to 1.37$)$ & $0.8,0.14(-2.05$ to 2.32$)$ & 0.54 \\
\hline All cancers & $201.2,8.00$ (5.81 to 10.18$)$ & $192.4,8.90$ (6.09 to 11.70$)$ & $93.6,7.71$ (3.22 to 12.20$)$ & $121.3,20.36$ (12.09 to 28.64 ) & 0.43 \\
\hline $\begin{array}{l}\text { All solid cancers, except brain } \\
\text { cancer after brain CT }\end{array}$ & $98.8,3.93$ (2.09 to 5.77 ) & $100.5,4.65$ (2.20 to 7.10$)$ & $75.5,6.23$ (2.09 to 10.37$)$ & $105.5,17.72$ (9.92 to 25.52$)$ & 0.01 \\
\hline $\begin{array}{l}\text { All cancers, except brain } \\
\text { cancer after brain CT }\end{array}$ & $141.1,5.61$ (3.43 to 7.79$)$ & $156.3,7.23$ (4.42 to 10.03$)$ & $77.6,6.40$ (1.91 to 10.89$)$ & $110.7,18.58$ (10.30 to 26.86 ) & 0.04 \\
\hline
\end{tabular}


Table 6 | Outcomes for the exposed group by cancer type, calendar year of first CT scan, and no of years since first CT exposure, based on a one year lag period

\begin{tabular}{|c|c|c|c|c|}
\hline \multirow{2}{*}{$\begin{array}{l}\text { No of years since first } \\
\text { exposure }\end{array}$} & \multicolumn{4}{|c|}{ Calendar year of first CT scan } \\
\hline & 1985-89 & $1990-94$ & $1995-99$ & $2000-05$ \\
\hline \multicolumn{5}{|l|}{ Brain cancer } \\
\hline $1-4$ & $38,5.09$ (3.60 to 6.99$)$ & $25,2.51$ (1.63 to 3.71$)$ & $25,2.06$ (1.34 to 3.05$)$ & $33,2.38$ (1.64 to 3.35$)$ \\
\hline $5-9$ & $38,3.81$ (2.70 to 5.23$)$ & $22,1.64$ (1.03 to 2.48$)$ & $20,1.31$ (0.80 to 2.02$)$ & $3,1.12(0.23$ to 3.27$)$ \\
\hline $10-14$ & $18,1.48(0.88$ to 2.34$)$ & $23,1.48(0.94$ to 2.21$)$ & $5,1.66(0.54$ to 3.88$)$ & - \\
\hline$\geq 15$ & $26,1.55$ (1.02 to 2.28$)$ & $7,2.46$ (0.99 to 5.07$)$ & - & - \\
\hline $\begin{array}{l}\text { All years since first } \\
\text { exposure }\end{array}$ & $120,2.61(2.17$ to 3.13$)$ & $77,1.84$ (1.47 to 2.32$)$ & $50,1.65$ (1.24 to 2.19$)$ & $36,2.16(1.53$ to 3.04$)$ \\
\hline \multicolumn{5}{|c|}{$\mathrm{P}<0.001$ for trend in IRR with calendar year of first CT scan, after accounting for years since first exposure } \\
\hline \multicolumn{5}{|l|}{ Other solid cancers } \\
\hline $1-4$ & $91,1.23$ (1.00 to 1.51$)$ & $140,1.20(1.01$ to 1.42$)$ & $208,1.29$ (1.13 to 1.48$)$ & $225,1.19(1.04$ to 1.36$)$ \\
\hline $5-9$ & $171,1.10(0.95$ to 1.28$)$ & $301,1.32(1.18$ to 1.48$)$ & $325,1.14(1.02$ to 1.28$)$ & $80,1.38(1.10$ to 1.72$)$ \\
\hline $10-14$ & $279,1.12(1.00$ to 1.26$)$ & $363,1.11(1.00$ to 1.23$)$ & $84,1.19(0.96$ to 1.48$)$ & - \\
\hline$\geq 15$ & $506,1.22(1.12$ to 1.34$)$ & $94,1.20$ (0.98 to 1.47$)$ & - & - \\
\hline $\begin{array}{l}\text { All years since first } \\
\text { exposure }\end{array}$ & $1047,1.17(1.10$ to 1.25$)$ & $898,1.20(1.12$ to 1.28$)$ & $617,1.20(1.10$ to 1.30$)$ & $305,1.24(1.10$ to 1.39$)$ \\
\hline \multicolumn{5}{|c|}{$P=0.68$ for trend in IRR with calendar year of first CT scan, after accounting for years since first exposure } \\
\hline \multicolumn{5}{|l|}{ All cancers } \\
\hline $1-4$ & $129,1.58(1.33$ to 1.88$)$ & $165,1.30(1.12$ to 1.52$)$ & $233,1.35$ (1.18 to 1.53$)$ & $258,1.27(1.13$ to 1.44$)$ \\
\hline $5-9$ & $209,1.26$ (1.10 to 1.45$)$ & $323,1.34$ (1.20 to 1.49$)$ & $345,1.15(1.04$ to 1.28$)$ & $83,1.36(1.10$ to 1.69$)$ \\
\hline $10-14$ & $297,1.14(1.01$ to 1.27$)$ & $386,1.12(1.02$ to 1.24$)$ & $89,1.20(0.98$ to 1.48$)$ & - \\
\hline$\geq 15$ & $532,1.24(1.14$ to 1.35$)$ & $101,1.24(1.02$ to 1.51$)$ & - & - \\
\hline $\begin{array}{l}\text { All years since first } \\
\text { exposure }\end{array}$ & $1167,1.24$ (1.17 to 1.32$)$ & $975,1.23(1.15$ to 1.31$)$ & $667,1.22(1.13$ to 1.32$)$ & $341,1.29(1.16$ to 1.44$)$ \\
\hline \multicolumn{5}{|c|}{$\mathrm{P}=0.18$ for trend in IRR with calendar year of first CT scan, after accounting for years since first exposure } \\
\hline
\end{tabular}




\begin{tabular}{|c|c|c|c|c|c|}
\hline & \multicolumn{4}{|c|}{ Age at first exposure (years) } & \multirow[b]{2}{*}{$P$ for trend } \\
\hline & $0-4$ & $5-9$ & $10-14$ & $15-19$ & \\
\hline \multicolumn{6}{|c|}{ Observed no of cancers in exposed group, IRR $(95 \% \mathrm{Cl})^{\star}$} \\
\hline Brain cancer & $31,3.01$ (2.11 to 4.30$)$ & $53,3.03$ (2.30 to 3.99$)$ & $68,1.93(1.51$ to 2.46$)$ & $131,1.82(1.53$ to 2.18$)$ & 0.001 \\
\hline After brain $\mathrm{CT}$ & $27,3.10(2.12$ to 4.54$)$ & $40,2.93$ (2.14 to 4.01$)$ & $48,2.08$ (1.56 to 2.78$)$ & $95,2.29$ (1.86 to 2.82$)$ & 0.09 \\
\hline After other CT & $4,2.52(0.94$ to 6.72$)$ & $13,3.37(1.95$ to 5.83$)$ & $20,1.63(1.04$ to 2.53$)$ & $36,1.17(0.84$ to 1.63$)$ & 0.002 \\
\hline $\begin{array}{l}\text { All solid cancers except brain } \\
\text { cancer }\end{array}$ & $53,1.76$ (1.34 to 2.31$)$ & $152,1.30$ (1.10 to 1.52$)$ & $520,1.16(1.06$ to 1.26$)$ & $1499,1.18(1.12$ to 1.24$)$ & 0.06 \\
\hline $\begin{array}{l}\text { Leukaemias and } \\
\text { myelodysplasias }\end{array}$ & $20,0.95(0.61$ to 1.48$)$ & $32,1.04(0.73$ to 1.48$)$ & $72,1.26(1.00$ to 1.60$)$ & $122,1.36(1.14$ to 1.64$)$ & 0.06 \\
\hline $\begin{array}{l}\text { Other lymphoid and } \\
\text { haematopoietic cancers }\end{array}$ & $22,1.83$ ( 1.20 to 2.79$)$ & $49,1.29(0.97$ to 1.71$)$ & $118,1.17$ (0.98 to 1.41$)$ & $208,1.10(0.95$ to 1.26$)$ & 0.04 \\
\hline All cancers & $126,1.72$ (1.44 to 2.05$)$ & $286,1.40$ (1.25 to 1.58$)$ & $778,1.21$ (1.13 to 1.30$)$ & $1960,1.21$ (1.16 to 1.27$)$ & $<0.001$ \\
\hline $\begin{array}{l}\text { All solid cancers, except brain } \\
\text { cancer after brain CT }\end{array}$ & $57,1.80$ (1.39 to 2.33$)$ & $165,1.36$ (1.17 to 1.59$)$ & $540,1.17$ (1.07 to 1.27$)$ & $1535,1.18(1.12$ to 1.24$)$ & 0.01 \\
\hline $\begin{array}{l}\text { All cancers, except brain cancer } \\
\text { after brain CT }\end{array}$ & $99,1.53$ (1.26 to 1.86$)$ & $246,1.29(1.14$ to 1.47$)$ & $730,1.18(1.10$ to 1.27$)$ & $1865,1.18(1.13$ to 1.24$)$ & 0.03 \\
\hline \multicolumn{6}{|c|}{ No of excess cancers in exposed group, EIR per 100000 person years $(95 \% \mathrm{Cl})^{*}$} \\
\hline Brain cancer & $20.7,4.37$ (2.07 to 6.68$)$ & $35.4,3.50$ (2.09 to 4.91$)$ & $32.6,1.71$ ( 0.86 to 2.56$)$ & $58.6,1.89$ (1.17 to 2.62$)$ & 0.16 \\
\hline after brain $\mathrm{CT}$ & $18.3,4.58$ (2.03 to 7.13$)$ & $26.3,3.36$ (1.77 to 4.94$)$ & $24.9,2.06$ (0.94 to 3.18$)$ & $53.3,3.05$ (1.96 to 4.15$)$ & 0.41 \\
\hline after other CT & $2.4,3.26(-2.04$ to 8.55$)$ & $9.2,4.01(0.91$ to 7.11$)$ & $7.7,1.10(-0.16$ to 2.35$)$ & $5.4,0.40(-0.47$ to 1.27$)$ & 0.03 \\
\hline $\begin{array}{l}\text { All solid cancers except brain } \\
\text { cancer }\end{array}$ & $22.9,4.83(1.82$ to 7.84$)$ & $34.6,3.42(1.04$ to 5.81$)$ & $70.6,3.70(1.36$ to 6.05$)$ & $227.7,7.36$ (4.91 to 9.81$)$ & 0.04 \\
\hline $\begin{array}{l}\text { Leukaemias and } \\
\text { myelodysplasias }\end{array}$ & $-1.0,-0.22(-2.07$ to 1.64$)$ & $1.3,0.13(-0.97$ to 1.22$)$ & $15.0,0.79(-0.09$ to 1.66$)$ & $32.6,1.05(0.35$ to 1.75$)$ & 0.01 \\
\hline $\begin{array}{l}\text { Other lymphoid and } \\
\text { haematopoietic cancers }\end{array}$ & $10.0,2.11$ (0.17 to 4.05$)$ & $11.0,1.08(-0.27$ to 2.44$)$ & $17.6,0.93(-0.19$ to 2.04$)$ & $18.8,0.61(-0.31$ to 1.52$)$ & 0.32 \\
\hline All cancers & $52.6,11.10(6.45$ to 15.74$)$ & $82.3,8.14$ (4.86 to 11.41$)$ & $135.8,7.12$ (4.25 to 9.99$)$ & $337.7,10.91$ (8.11 to 13.72$)$ & 0.41 \\
\hline $\begin{array}{l}\text { All solid cancers, except brain } \\
\text { cancer after brain CT }\end{array}$ & $25.3,5.34$ (1.55 to 9.13$)$ & $43.8,4.33$ ( 1.55 to 7.10$)$ & $78.2,4.10$ (1.61 to 6.60$)$ & $233.1,7.53$ (4.98 to 10.09$)$ & 0.21 \\
\hline $\begin{array}{l}\text { All cancers, except brain cancer } \\
\text { after brain CT }\end{array}$ & $34.3,7.23$ (2.59 to 11.88$)$ & $56.0,5.54$ (2.26 to 8.82$)$ & $110.9,5.82$ (2.95 to 8.69$)$ & $284.5,9.19$ (6.39 to 12.00$)$ & 0.22 \\
\hline
\end{tabular}

$I R R=$ incidence rate ratio, exposed $v$ unexposed; $E I R=$ absolute excess incidence rate compared with rates in unexposed group.

${ }^{*} I R R, E I R$, and number of excess cancers calculated after stratification for age, sex, and year of birth. 
Table 8| Approximate radiation doses and cancer risks per unit dose for lag periods of one, five, and 10 years from first exposure to CT scanning

\begin{tabular}{|c|c|c|c|}
\hline \multirow[b]{2}{*}{ Cancer risk to date and type of exposure } & \multicolumn{3}{|c|}{ Lag period (years) } \\
\hline & 1 & 5 & 10 \\
\hline \multicolumn{4}{|c|}{ All cancers, except brain cancers after brain CT (all exposures) } \\
\hline Absolute no of excess cancers to date & 486 & 340 & 183 \\
\hline Collective effective dose (Sv) & 3900 & 3100 & 1900 \\
\hline No of CT exposures & 866580 & 684386 & 401811 \\
\hline Average effective dose per scan $(\mathrm{mSv})^{\star}$ & 4.5 & 4.5 & 4.7 \\
\hline Absolute no of excess cancers to date per Sv & 0.125 & 0.110 & 0.096 \\
\hline Proportion of CTs to date followed by an excess cancer & 1 in 1800 & 1 in 2000 & 1 in 2200 \\
\hline No of people exposed & 680211 & 544354 & 327216 \\
\hline Average dose per exposed person (mSv) & 5.7 & 5.7 & 5.8 \\
\hline IRR (exposed $v$ unexposed) $\dagger$ & $1.20(1.15$ to 1.24$)$ & $1.18(1.13$ to 1.23$)$ & $1.16(1.10$ to 1.22$)$ \\
\hline Excess rate ratio per $m S v \neq \rrbracket$ & 0.035 (0.026 to 0.042$)$ & $0.031(0.022$ to 0.040$)$ & $0.027(0.017$ to 0.037$)$ \\
\hline \multicolumn{4}{|l|}{ Brain cancers after brain CT (brain exposures) } \\
\hline Absolute no of excess brain cancers to date & 123 & 62 & 26 \\
\hline Collective organ dose (brain; Gy) & 19800 & 16200 & 10200 \\
\hline No of brain CTs & 494003 & 405230 & 254010 \\
\hline Average brain dose per scan $(m G y)^{*}$ & 40 & 40 & 40 \\
\hline Absolute no of excess brain cancers to date per Gy & 0.006 & 0.004 & 0.003 \\
\hline $\begin{array}{l}\text { Proportion of CTs to date followed by an excess brain } \\
\text { cancer }\end{array}$ & 1 in 4000 & 1 in 6500 & 1 in 9800 \\
\hline No of people exposed & 404105 & 334203 & 212481 \\
\hline Average dose per exposed person (mGy) & 49 & 48 & 48 \\
\hline IRR (exposed $v$ unexposed) $\dagger$ & 2.44 (2.12 to 2.81 ) & 2.02 (1.69 to 2.43 ) & $1.74(1.35$ to 2.25$)$ \\
\hline Excess rate ratio per mGy§ & 0.029 (0.023 to 0.037$)$ & $0.021(0.014$ to 0.029$)$ & $0.015(0.007$ to 0.026$)$ \\
\hline \multicolumn{4}{|l|}{ Leukaemias and myelodysplasias (all exposures) } \\
\hline $\begin{array}{l}\text { Absolute no of excess leukaemias and myelodysplasias } \\
\text { to date }\end{array}$ & 48 & 31 & 6 \\
\hline Collective organ dose (red bone marrow) (Gy) & 4000 & 3200 & 1700 \\
\hline No of CTs & 866580 & 684386 & 401811 \\
\hline Average red bone marrow dose per scan (mGy) * & 4.6 & 4.7 & 4.2 \\
\hline $\begin{array}{l}\text { Absolute no of excess leukaemias and myelodysplasias } \\
\text { to date per Gy }\end{array}$ & 0.012 & 0.010 & 0.004 \\
\hline $\begin{array}{l}\text { Proportion of CTs to date followed by an excess } \\
\text { leukaemia or myelodysplasia }\end{array}$ & 1 in 18000 & 1 in 22000 & 1 in 67000 \\
\hline No of people exposed & 680211 & 544354 & 327216 \\
\hline Average dose per exposed person (mGy) & 5.9 & 5.9 & 5.2 \\
\hline IRR (exposed $v$ unexposed) $\dagger$ & $1.23(1.08$ to 1.41$)$ & $1.25(1.06$ to 1.47$)$ & $1.09(0.85$ to 1.40$)$ \\
\hline Excess rate ratio per mGy§ & $0.039(0.014$ to 0.070$)$ & $0.042(0.010$ to 0.080$)$ & $0.017(-0.029$ to 0.078$)$ \\
\hline
\end{tabular}

*Average effective doses and doses to specific organs by CT type were taken from published and local sources (see Methods), and summed over the number of exposures to give indicative collective doses for the exposed population.

tCalculated after stratification for age, sex and year of birth, as in tables 3-7.

$\ddagger(I R R-1) \div$ average effective dose per exposed person.

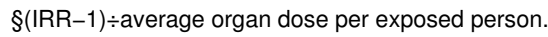

TThe risk coefficients shown are based on the assumption that no radiation related cancers occurred before the end of the assumed lag period, that all the excess cancers occurring after the lag period and during the period of follow-up were caused by radiation exposure, and that no radiation related cancers occurred after the end of the current follow-up period. To the extent that these assumptions prove to be incorrect, then the coefficients given here will either overestimate or underestimate the risk. 


\begin{tabular}{|c|c|c|c|c|}
\hline $\begin{array}{l}\text { Study population } \\
\text { and age at } \\
\text { exposure }\end{array}$ & Site of cancer & Period of follow-up & Quantity estimated & Estimate $(95 \% \mathrm{Cl})^{\star}$ \\
\hline \multicolumn{5}{|l|}{ Present study } \\
\hline \multirow[t]{6}{*}{$0-19$ years } & Leukaemias and myelodysplasias & $\begin{array}{l}\text { Study members followed for } 9.5 \text { years on } \\
\text { average, after exclusion of first year }\end{array}$ & $\begin{array}{l}\text { ERR per mGy of bone marrow } \\
\text { dose }\end{array}$ & $0.039(0.014$ to 0.070$)$ \\
\hline & $\begin{array}{l}\text { Leukaemia, excluding } \\
\text { myelodysplasias }\end{array}$ & $\begin{array}{l}\text { Study members followed for } 7.3 \text { years on } \\
\text { average, after exclusion of first five years }\end{array}$ & $\begin{array}{l}\text { ERR per mGy of bone marrow } \\
\text { dose }\end{array}$ & $0.035(0.000$ to 0.077$)$ \\
\hline & Brain cancer after brain $\mathrm{CT}$ & $\begin{array}{l}\text { Study members followed for } 7.3 \text { years on } \\
\text { average, after exclusion of first five years }\end{array}$ & ERR per mGy of brain dose & $0.021(0.014$ to 0.029$)$ \\
\hline & Brain cancer after brain $\mathrm{CT}$ & $\begin{array}{l}\text { Study members followed for } 5.5 \text { years on } \\
\text { average, after exclusion of first } 10 \text { years }\end{array}$ & ERR per mGy of brain dose & $0.015(0.007$ to 0.026$)$ \\
\hline & $\begin{array}{l}\text { All cancers other than brain cancer } \\
\text { after brain CT }\end{array}$ & $\begin{array}{l}\text { Study members followed for } 9.5 \text { years on } \\
\text { average, after exclusion of first year }\end{array}$ & ERR per mSv of effective dose & $0.035(0.026$ to 0.042$)$ \\
\hline & $\begin{array}{l}\text { Solid cancers other than brain } \\
\text { cancer after brain CT }\end{array}$ & $\begin{array}{l}\text { Study members followed for } 5.5 \text { years on } \\
\text { average, after exclusion of first } 10 \text { years }\end{array}$ & ERR per mSv of effective dose & $0.027(0.017$ to 0.037$)$ \\
\hline \multicolumn{5}{|c|}{ Young people exposed to CT scans in the UK in 1985-2008 } \\
\hline \multirow[t]{2}{*}{$0-21$ years } & Leukaemias and myelodysplasias $^{12}$ & $\begin{array}{l}\text { Study members followed for } 9.6 \text { years on } \\
\text { average, after exclusion of first two years }\end{array}$ & $\begin{array}{l}\text { ERR per mGy of bone marrow } \\
\text { dose }\end{array}$ & $0.036(0.005$ to 0.120$)$ \\
\hline & Brain cancer $^{12}$ & $\begin{array}{l}\text { Study members followed for } 6.7 \text { years on } \\
\text { average, after exclusion of first five years }\end{array}$ & ERR per mGy of brain dose & $0.023(0.010$ to 0.049$)$ \\
\hline \multicolumn{5}{|c|}{ Life Span Study of survivors of atomic bombings in Japan in 1945} \\
\hline \multirow[t]{3}{*}{$0-19$ years } & $\begin{array}{l}\text { Leukaemias, excluding } \\
\text { myelodysplasias }^{18}\end{array}$ & $1950-60$ & $\begin{array}{l}\text { ERR per mGy of bone marrow } \\
\text { dose }\end{array}$ & $0.045(0.016$ to 0.188$)$ \\
\hline & Brain cancer $^{40}$ & $1958-65$ & ERR per mSv of brain dose & $0.006(0.000$ to 0.064$)$ \\
\hline & $\begin{array}{l}\text { Solid cancers other than brain } \\
{\text { cancer }{ }^{40}}^{40}\end{array}$ & $1958-65$ & ERR per mSv of colon dose & $0.003(0.002$ to 0.006$)$ \\
\hline
\end{tabular}

ERR=Excess rate ratio.

${ }^{*}$ For male and female members combined.

†M Little (National Cancer Institute), personal communication, March 2013. 


\section{Figures}

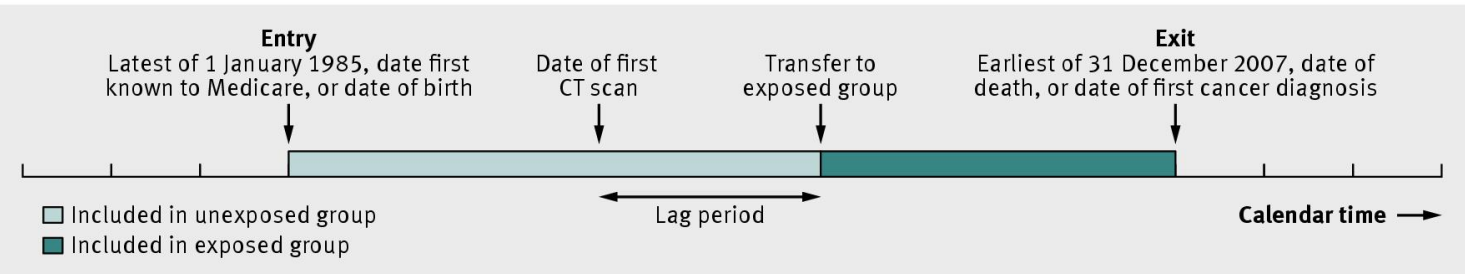

Fig 1 Schematic diagram showing how study members contributed to unexposed and exposed groups. All study members were classified as unexposed on entry to the study. Those who were exposed to a CT scan remained in the unexposed group for the duration of the lag period (one year in most analyses, but five or 10 years in some). They were then transferred to the exposed group, provided that their date of transfer was before their date of exit from the study. Study members who had no CT scan remained in the unexposed group for the duration of the study

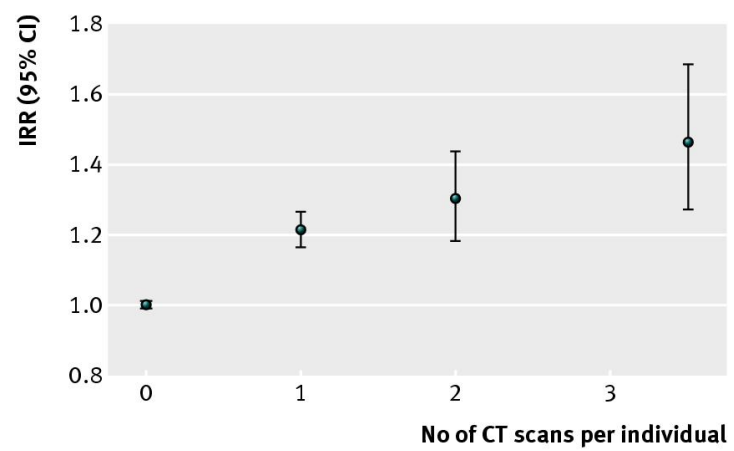

Fig 2 Incidence rate ratios (IRR) for all types of cancers in exposed versus unexposed individuals based on a one year lag period, by the number of CT scans. The IRR increased by 0.16 ( $95 \%$ confidence interval 0.13 to 0.19$)$ for each additional CT scan, calculated after stratification for age, sex, and year of birth $\left(X^{2}=131.4\right.$ and $P<0.001$ for trend). If unexposed people were excluded, the trend remained significant $\left(X^{2}=5.79\right.$ and $P=0.02$ for trend). The average number of scans among individuals exposed to three or more scans was 3.5. (Web figure A shows corresponding results based on lag periods of five and 10 years) 


\begin{tabular}{|c|c|c|c|}
\hline Cancer type by CT site & $\begin{array}{l}\text { er of cancers } \\
\text { exposed }\end{array}$ & IRR (95\% CI) & IRR (95\% Cl) \\
\hline $\begin{array}{l}\text { Brain } \\
\text { Melanoma }\end{array}$ & 511 & $\rightarrow$ & $1.14(1.04$ to 1.24$)$ \\
\hline Soft tissue & 69 & $\longrightarrow$ & $1.64(1.28$ to 2.09$)$ \\
\hline Brain & 210 & & $2.44(2.12$ to 2.81$)$ \\
\hline Thyroid & 155 & $\rightarrow$ & $1.33(1.13$ to 1.57$)$ \\
\hline Other solid cancers & 633 & - & $1.13(1.05$ to 1.23$)$ \\
\hline Leukaemias and myelodysplasias & 149 & $\leftarrow$ & $1.16(0.99$ to 1.37$)$ \\
\hline Other lymphoid and haematopoietic & 237 & - & 1.13 (0.99 to 1.29$)$ \\
\hline All cancers & 1964 & $\cdot$ & 1.23 (1.18 to 1.29$)$ \\
\hline Facial bones & & & \\
\hline Melanoma & 76 & $=$ & $1.12(0.89$ to 1.40$)$ \\
\hline Soft tissue & 9 & & $1.30(0.67$ to 2.52$)$ \\
\hline Brain & 21 & & $1.60(1.04$ to 2.47$)$ \\
\hline Thyroid & 28 & & $1.53(1.05$ to 2.22$)$ \\
\hline Other solid cancers & 83 & - & $1.02(0.83$ to 1.27$)$ \\
\hline Leukaemias and myelodysplasias & 22 & & $1.07(0.70$ to 1.62$)$ \\
\hline Other lymphoid and haematopoietic & 41 & ـــ & $1.10(0.81$ to 1.49$)$ \\
\hline All cancers & 280 & $\rightarrow$ & $1.14(1.01$ to 1.28$)$ \\
\hline Chest & & & \\
\hline Melanoma & 8 & & 0.97 (0.49 to 1.95$)$ \\
\hline Soft tissue & 4 & & 4.64 (1.74 to 12.4$)$ \\
\hline Brain & 3 & & $1.74(0.56$ to 5.41$)$ \\
\hline Thyroid & 3 & & $1.41(0.45$ to 4.38$)$ \\
\hline Other solid cancers & 20 & & $1.96(1.26$ to 3.04$)$ \\
\hline Leukaemias and myelodysplasias & 2 & & 0.74 (0.18 to 2.95$)$ \\
\hline Other lymphoid and haematopoietic & 9 & & $2.02(1.05$ to 3.89$)$ \\
\hline All cancers & 49 & $\longrightarrow$ & $1.62(1.22$ to 2.14$)$ \\
\hline Extremities & & & \\
\hline Melanoma & 68 & $\rightarrow$ & 1.24 (0.97 to 1.57$)$ \\
\hline Soft tissue & 14 & & $2.57(1.51$ to 4.37$)$ \\
\hline Brain & 16 & & $1.56(0.95$ to 2.55$)$ \\
\hline Thyroid & 16 & & $1.19(0.73$ to 1.94$)$ \\
\hline Other solid cancers & 92 & $\longrightarrow$ & $1.36(1.11$ to 1.67$)$ \\
\hline Leukaemias and myelodysplasias & 22 & & $1.42(0.93$ to 2.16$)$ \\
\hline Other lymphoid and haematopoietic & 33 & $=$ & $1.13(0.80$ to 1.60$)$ \\
\hline All cancers & 261 & $\rightarrow$ & $1.33(1.18$ to 1.50$)$ \\
\hline Abdomen, pelvis & & & \\
\hline Melanoma & 37 & $\longrightarrow$ & $1.30(0.94$ to 1.79$)$ \\
\hline Soft tissue & 6 & & $2.33(1.04$ to 5.21$)$ \\
\hline Brain & 11 & & $2.21(1.22$ to 4.00$)$ \\
\hline Thyroid & 12 & & $1.47(0.83$ to 2.59$)$ \\
\hline Other solid cancers & 49 & $\longrightarrow$ & 1.45 (1.10 to 1.92$)$ \\
\hline Leukaemias and myelodysplasias & 24 & & $3.24(2.17$ to 4.84$)$ \\
\hline Other lymphoid and haematopoietic & 20 & & $1.48(0.96$ to 2.30$)$ \\
\hline All cancers & 159 & $\rightarrow$ & 1.61 (1.38 to 1.88$)$ \\
\hline Spine, neck & & & \\
\hline Melanoma & 61 & - & $0.93(0.72$ to 1.20$)$ \\
\hline Soft tissue & 10 & & $1.78(0.95$ to 3.32$)$ \\
\hline Brain & 13 & $\rightarrow$ & $1.19(0.69$ to 2.05$)$ \\
\hline Thyroid & 29 & & $1.78(1.24$ to 2.58$)$ \\
\hline Other solid cancers & 81 & - & $1.02(0.82$ to 1.27$)$ \\
\hline Leukaemias and myelodysplasias & 20 & & $1.31(0.85$ to 2.04$)$ \\
\hline Other lymphoid and haematopoietic & 38 & $\rightarrow$ & $1.29(0.94$ to 1.77$)$ \\
\hline All cancers & 252 & - & $1.13(1.00$ to 1.28$)$ \\
\hline Other/unknown & & & \\
\hline Melanoma & 48 & - & 1.03 (0.77 to 1.36$)$ \\
\hline Soft tissue & 7 & & $1.95(0.93$ to 4.10$)$ \\
\hline Brain & 9 & & $1.23(0.64$ to 2.37$)$ \\
\hline Thyroid & 15 & $\longrightarrow$ & $1.38(0.83$ to 2.29$)$ \\
\hline Other solid cancers & 80 & $\longrightarrow$ & $1.30(1.05$ to 1.62$)$ \\
\hline Leukaemias and myelodysplasias & 7 & & $0.81(0.38$ to 1.69$)$ \\
\hline Other lymphoid and haematopoietic & 19 & $\rightarrow$ & $1.17(0.75$ to 1.84$)$ \\
\hline All cancers & 185 & $\rightarrow$ & $1.19(1.03$ to 1.38$)$ \\
\hline All CTs & & & \\
\hline Melanoma & 809 & - & $1.12(1.04$ to 1.20$)$ \\
\hline Soft tissue & 119 & 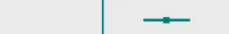 & $1.78(1.47$ to 2.16$)$ \\
\hline Brain & 283 & $=$ & $2.13(1.88$ to 2.41$)$ \\
\hline Thyroid & 258 & $\rightarrow$ & $1.40(1.23$ to 1.59$)$ \\
\hline Other solid cancers & 1038 & - & $1.16(1.09$ to 1.24$)$ \\
\hline Leukaemias and myelodysplasias & 246 & $\rightarrow$ & $1.23(1.08$ to 1.41$)$ \\
\hline Other lymphoid and haematopoietic & 397 & - & $1.17(1.06$ to 1.30$)$ \\
\hline All cancers & 3150 & - & 1.24 (1.20 to 1.29$)$ \\
\hline & 0.25 & 0.5 & 8 \\
\hline
\end{tabular}

Fig 3 Incidence rate ratios (IRR) for exposed versus unexposed by site of CT scan and type of cancer, based on a one year lag period. IRRs were calculated after stratification for age, sex, and year of birth. Heterogeneity between cancer types, by site of CT scan exposure: all sites, $X^{2}=23.58$ ( $6 \mathrm{df}$ ), $P=0.001$; brain, $X^{2}=104.1$ ( $\left.6 \mathrm{df}\right), P<0.001$; abdomen or pelvis, $X^{2}=15.7$ $(6 \mathrm{df}), P=0.02$. Heterogeneity between sites of $C T$ scan exposure, by cancer type: all cancers, $X^{2}=111.1(6 \mathrm{df}), P<0.001$; brain, $X^{2}=13.9$ ( $\left.6 \mathrm{df}\right), P=0.03$; leukaemia, $X^{2}=24.81$ ( $\left.6 \mathrm{df}\right), P<0.001$ 